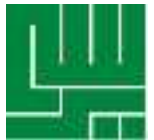

\title{
Gambaran Sindrom Ekstrapiramidal Pada Pasien Skizofrenia Yang Mendapat Terapi Antipsikotik
}

\section{Extrapyramal syndrome overview In schizophrenia patients with antipsychotic therapy}

\author{
Dita Hasni ${ }^{1}$,Muhammad Ridho ${ }^{2}$, Mutiara Anissa ${ }^{3}$ \\ 1BagianFarmakologi, Fakultas KedokteranUniversitas Baiturrahmah, Padang, \\ Indonesia \\ ${ }^{2}$ Fakultas Kedokteran,Universitas Baiturrahmah, Padang, Indonesia \\ ${ }^{3}$ Bagian Psikiatri, Fakultas Kedokteran, Universitas Baiturrahmah, Padang, \\ Indonesia
}

\section{KATA KUNCI KEYWORDS}

ABSTRAK
Antipsikotik, EPS, Skizofrenia

Antipsychotics, EPS, Schizophrenia

Prevalensi skizofrenia di Sumatra Barat adalah 1.9 per seribu penduduk. Terap iutam askizofrenia adalah obat antipsikotik. Penggunaan antipsikotik dapat menyebabkan efek samping berupa sindrom ekstrapiramidal (EPS) pada pasien skizofrenia, yang dapat meningkatkan morbiditas, menurunkan kepatuhan, dan menurunkan kualitas hidup. Penelitian ini bertujuan untuk melihat gambaran kejadian efek samping sindrom ekstrapiramidal yang terjadi pada pasien skizofrenia yang mendapatkan terapi antipsikotik. Diikutsertakan 89 pasien pada penelitian cross sectional ini. Pengambilan data dilakukan secara consecutive sampling di polirawat jalan RSJ HB Saanin Padang setelah memenuhi criteria inklusi dan ekslusi. Penelitian ini menggunakan kuisioner Simpson Angus Extrapyramidal Side Effect Scale sebagai penentuan kriteria EPS. Pada penelitian ini diperoleh data pasien skizofrenia yang mengalami efek samping EPS sebesar 41,6\%, dengan anti psikotiktipikal sebesar 60\%, anti psikotikatipikal sebesar 35.8\%, dan anti psikotik kombinasi sebesar $48.4 \%$ dari total responden. Pada penelitian ini diperoleh EPS yang banyak diderita adalah parkinsonisme.

The prevalence of schizophrenia in West Sumatra is 1.9 per thousand inhabitants (Riskesdas, 2013). The main therapy for schizophrenia is anti-psychotic medication. The use of antipsychotics can cause the side effects of extrapyramidal syndrome (EPS) in schizophrenic patients, which can increase morbidity, decrease medication adherence, and decrease quality of life. This study aims to see the illustration of the incidence of extrapyramidal syndrome side effects occurring in schizophrenic patients receiving antipsychotic therapy. Including 89 patients 
in this cross-sectional study. The data were collected by consecutive sampling at RSJ HB Saanin Padang outpatient clinic after fulfilling the inclusion and exclusion criteria. This research used Simpson Angus Extrapyramidal Side Effect Scale questionnaire as determination of EPS criteria. Schizophrenia patients with EPS side-effects were $41.6 \%$, with typical antipsychotics $60 \%$, atypical antipsychotics 35.8\%, and combination antipsychotic $48.4 \%$ of total respondents. In this study obtained EPS that suffered is Parkinsonisme

\section{PENDAHULUAN}

Skizofrenia merupakan salah satu gangguan jiwa berat yang berupa kumpulan gejala klinis yang bervariasi dan sangat mengganggu, serta psikopatologi yang melibatkan kognitif, emosi, persepsi dan aspek lain dari tingkah laku (Handayani et al., 2017). Prevalensi skizofrenia di Indonesia sebesar 1,7 per seribu penduduk, sedangkan prevalensi skizofrenia di sumatera barat sebesar 1,9 per seribu penduduk (Badan Penelitian dan Pengembangan Kesehatan, 2013) Antipsikotik merupakan terapi utama pada pasien Skizofrenia (Maria Jarut and Wiyono, 2013). Penggunaan antipsikotik dalam jangka panjang dapat menyebabkan efek negatif yang tidak diinginkan, salah satunya adalah sindrom ekstrapiramidal (EPS) (Tandon, 2011). Penelitian ini memiliki tujuan untuk mendapatkan gambaran sindrom ekstrapiramidal pada pasien skizofrenia yang mendapatkan terapi antipsikotik di RSJ HB Saa'nin Padang.

\section{METODE}

Penelitian ini melibatkan 89 orang subjek yang direkrut dengan metode consecutive sampling setelah memenuhi kriteria inklusi dan ekslusi. Subjek diinklusi jika telah didiagnosis dengan skizofrenia oleh psikiater berdasarkan DSM V, telah mendapatkan terapi antipsikotik lebih dari 3 bulan, menjalani terapi rawat jalan di Poli RSJ HB Saanin Padang dan bersedia menandatangani inform concent setelah diberi penjelasan. Pasien diekslusikan jika dalam kondisi tidak kooperatif. Penelitian ini bersifat deskriptif kategorik, dengan rancangan potong lintang. Data kategorik akan disajikan dalam bentuk frekuensi dan distribusi, data numerik akan disajikan dalam bentuk rerata dan standar deviasi.

\section{HASIL}

Penelitian ini melibatkan 89 pasien rawat jalan di RSJ HB.Saanin Padang yang telah didiagnosis dengan Skizofrenia berdasarkan DSM V. Diperoleh hasil, subjek penelitian mayoritas berada pada kelompok usia 31-40 tahun, berjenis kelamin laki-laki, dan tidak bekerja. Data bisa dilihat pada tabel 1.
Correspondence:

Dita Hasni, Bagian Farmakologi, Fakultas Kedokteran, Universitas Baiturrahmah, Padang, Sumatera Barat.,

Email:ditahasni@fk.unbrah.ac.id 
Tabel.1 Karakteristik DemografiSubjek Penelitian

\begin{tabular}{|c|c|c|}
\hline Variabel & $N$ & $\%$ \\
\hline \multicolumn{3}{|l|}{ Usia } \\
\hline 18-30 tahun & 26 & 29,2 \\
\hline 31-40 tahun & 40 & 44,9 \\
\hline 41-50 tahun & 14 & 15,7 \\
\hline 51-60 tahun & 8 & 9,0 \\
\hline 61-70 tahun & 1 & 1,1 \\
\hline \multicolumn{3}{|l|}{ Jenis Kelamin } \\
\hline laki-laki & 64 & 71,9 \\
\hline Perempuan & 25 & 28,1 \\
\hline \multicolumn{3}{|l|}{ Bekerja } \\
\hline $\mathrm{Ya}$ & 32 & 36,0 \\
\hline Tidak & 57 & 64,0 \\
\hline Total & 89 & 100,0 \\
\hline \multicolumn{3}{|c|}{ 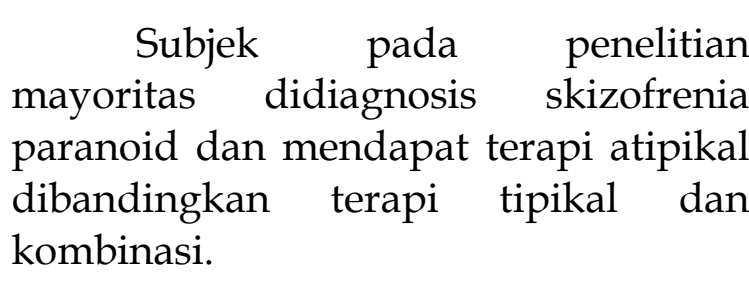 } \\
\hline \multicolumn{3}{|c|}{$\begin{array}{l}\text { Tabel 2. Karakteristik Klinis Subjek } \\
\text { Penelitian }\end{array}$} \\
\hline Variabel & $n$ & $\%$ \\
\hline \multicolumn{3}{|l|}{ Diagnosis } \\
\hline $\begin{array}{l}\text { Skizofrenia } \\
\text { Paranoid }\end{array}$ & 59 & 66,3 \\
\hline $\begin{array}{l}\text { Skizofrenia tak } \\
\text { terinci }\end{array}$ & 16 & 18,0 \\
\hline $\begin{array}{l}\text { Skizofrenia lain } \\
\text { nya }\end{array}$ & 14 & 15,7 \\
\hline \multicolumn{3}{|l|}{ Obat } \\
\hline Tipikal & 5 & 5,6 \\
\hline Atipikal & 53 & 59,6 \\
\hline Kombinasi & 31 & 34,8 \\
\hline Total & 89 & 100,0 \\
\hline
\end{tabular}

Penelitian ini juga memperoleh data terdapat $41,6 \%$ subjek penelitian yang mengalami gejala ekstrapiramidal sindrom. Dan pasien yang mendapat antipsikotik tipikal 60\% mengalami EPS.
Tabel 3. Gambaran efek samping Ekstrapiramidal sindrom (EPS) pada penggunaan antipsikotik

\begin{tabular}{lcc} 
Variable & $\begin{array}{c}\text { Ada } \\
\boldsymbol{n}(\boldsymbol{\%})\end{array}$ & $\begin{array}{c}\text { Tidak } \\
\boldsymbol{n}(\boldsymbol{\%})\end{array}$ \\
\hline $\begin{array}{l}\text { Obat } \\
\text { antipsikotik }\end{array}$ & $\mathbf{3 7 ( 4 1 , 6 )}$ & $\mathbf{5 2}(\mathbf{5 8 , 4 )}$ \\
Tipikal & $3(60,0)$ & $2(40,0)$ \\
Atipikal & $19(35,8)$ & $34(64,2)$ \\
Kombinasi & $15(48,4)$ & $16(51,6)$ \\
\hline
\end{tabular}

\section{PEMBAHASAN}

Pada penelitian ini didapatkan pasien skizofrenia yang mendapat antipsikotik dengan gejala EPS adalah sebanyak 41,6\% dari total responden. Penggunaan antipsikotik dapat menyebabkan EPS karena obat ini menimbulkan efek penurunan aktivitas neurotransmitter dopamin di jalur nigrostriatal akibat blokade obat pada reseptor dopamin. Sindrom ekstrapiramidal dapat muncul setelah beberapa hari sampai beberapa minggu setelah penggunaan antipsikotik (Stroup and Gray, 2018).

Pada Penelitian ini didapatkan data $60 \%$ darisubyek penelitian yang mendapat terapi antipsikotik tipikal mengalami efek samping sindrom ekstrapiramidal. Hasil penelitian ini selaras dengan teori bahwa, efek antipsikotik pada golongan tipikal ini terjadi melalui antagonisme di reseptor dopaminergik D2 yang terdapat di traktus dopaminergik di otak yang meliputi mesokortikal, mesolimbik, tubero infundibular dan traktus nigrostriatal.. Mekanisme yang menghambat reseptor dopamin D2 dijalur nigrostriatal dapat menimbulkan gangguan di ganglia basal yang menyebabkan terjadinya efek samping sindrom ekstrapiramidal (Meltzer, 2013). Kebanyakan peneliti memperkirakan bahwa sindrom 
ekstrapiramidal muncul pada sekitar $90 \%$ dari pasien yang diobati dengan antipsikotik generasi pertama, seperti haloperidol (Duma and Fung, 2019).

Pada penelitian ini didapatkan hasil pasien yang mendapatkan terapi antipsikotik atipikal dan mengalami sindrom ekstrapiramidal sebanyak $35,8 \%$. Hasil penelitian ini selaras dengan teori yang disampaikan kaplan bahwa antipsikotik atipikal dimana mekanisme kerja obat ini rendah terhadap reseptor dopamin sedangkan terhadap 5HT2 tinggi, hal ini yang menyebabkan rendahnya efek sindrom ekstrapiramidal (Rofman, 2009).

Pada penelitian ini didapatkan data pasien yang mendapat terapi antipsikotik kombinasi yang mengalami sindrom ekstrapiramidal adalah sebanyak 35,8\%. Hasil penelitian ini selaras dengan hasil penelitian Siwi yang melaporkan bahwa terapi antipsikotik kombinasi merupakan terapi yang banyak diberikan kepada pasien (Padmasari and Sugiyono, 2017).

Antipsikotik kombinasi yang paling sering digunakan adalah antipsikotik kombinasi antara antipsikotik generasi pertama dan antipsikotik generasi kedua. Semakin banyak kombinasi yang digunakan maka semakin besar pula kemungkinan terjadinya resiko efek samping, efek samping yang terjadi berdasarkan kekuatan afinitas pada setiap reseptor yang diduduki dari masing-masing obat yang dikombinasikan. Terapi kombinasi dapat menguntungkan karena bekerja secara sinergis, namun hal tersebut kemungkinan menimbulkan peningkatan efek samping. Keseluruhan efek samping yang terjadi pada setiap penggunaan obat antipsikotik kombinasi ini yang paling sering muncul adalah sindrom ekstrapiramidal, efek antikolinergik dan sedasi (Gallego et al., 2012; Lally and MacCabe, 2015).

\section{SIMPULAN DAN SARAN}

\section{Simpulan}

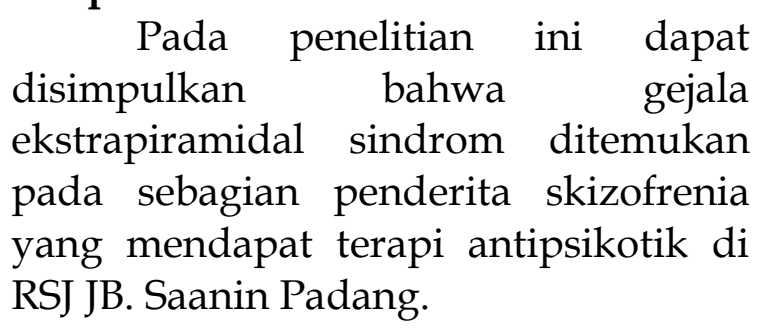

\section{Saran}

Penelitian ini dapat dilanjutkan mengenai hubungan kepatuhan mengkonsumsi obat dengan derajat keparahan ekstrapiramidal sindrom.

\section{KEPUSTAKAAN}

Badan Penelitian dan Pengembangan Kesehatan 2013. 'Riset Kesehatan Dasar 2013',Riset Kesehatan Dasar 2013.

Duma SR and FungVSC 2019. 'Druginduced movement disorders', Australian Prescriber. doi: 10.18773/austprescr.2019.014.

GallegoJAet al., 2012. 'Safety and tolerability of antipsychotic polypharmacy', Expert Opinion on Drug Safety. doi: 10.1517/14740338.2012.683523.

Handayani L et al., 2017. 'FAKTOR RISIKO KEJADIAN SKIZOFRENIA DI RUMAH SAKIT JIWA GRHASIA DAERAH ISTIMEWA YOGYAKARTA (DIY)', HUMANITAS. doi: 10.26555/humanitas.v13i2.6069.

Lally Jand MacCabe JH 2015. 'Antipsychotic medication in schizophrenia: A review', British Medical Bulletin. doi: 10.1093/bmb/ldv017.

Maria Jarut Y and Wiyono WI 2013. 'TINJAUAN PENGGUNAAN ANTIPSIKOTIK

PADA 
PENGOBATAN SKIZOFRENIA DI RUMAH SAKIT PROF. DR. V. L. RATUMBUYSANG MANADO PERIODE JANUARI 2013-MARET 2013', PHARMACON Jurnal Ilmiah Farmasi-UNSRAT, 2(03), pp. 54-57.

Meltzer HY 2013. 'Update on Typical and Atypical Antipsychotic Drugs', Annual Review of Medicine, 64(1), pp. 393-406. doi: $\quad$ 10.1146/annurev-med-050911161504.

Padmasari Sand Sugiyono S2017. 'EVALUASI RASIONALITAS PENGGUNAAN OBAT ANTIPSIKOTIK PADA PASIEN SKIZOFRENIA PARANOID DI INSTALASI RAWAT INAP RUMAH SAKIT

AMINO
GONDOHUTOMO PROVINSI JAWA TENGAH', Acta Holist. Pharm, 1(1), pp. 25-32. Available at: https://ojs.farmasimahaganesha.ac.id /index.php/AHP/article/view/10.

Rofman ES 2009. 'Kaplan and Sadock's Synopsis of Psychiatry', The Journal of Clinical Psychiatry. doi: 10.4088/jcp.09bk05044.

Stroup TS and GrayN 2018. 'Management of common adverse effects of antipsychotic medications', World Psychiatry, 17(3), pp. 341-356. doi: 10.1002/wps.20567.

TandonR2011. 'Antipsychotics in the treatment of schizophrenia: An overview', Journal of Clinical Psychiatry. doi: 10.4088/JCP.10075su1.01. 